\title{
Neuroprotective and anti-oxidant effects of caffeic acid isolated from Erigeron annuus leaf
}

\author{
Chang-Ho Jeong ${ }^{1}$, Hee Rok Jeong ${ }^{2}$, Gwi Nam Choi², Dae-Ok Kim', Uk Lee ${ }^{3}$ and Ho Jin Heo ${ }^{2 *}$
}

\begin{abstract}
Background: Since oxidative stress has been implicated in a neurodegenerative disease such as Alzheimer's disease (AD), natural antioxidants are promising candidates of chemopreventive agents. This study examines antioxidant and neuronal cell protective effects of various fractions of the methanolic extract of Erigeron annuus leaf and identifies active compounds of the extract.

Methods: Antioxidant activities of the fractions from Erigeron annuus leaf were examined with [2,2-azino-bis(3ethylbenz thiazoline-6-sulfonic acid diammonium salt)] (ABTS) and ferric reducing antioxidant power (FRAP) assays. Neuroprotective effect of caffeic acid under oxidative stress induced by $\mathrm{H}_{2} \mathrm{O}_{2}$ was investigated with [3-(4,5dimethythiazol-2-yl)-2,5-diphenyl tetrazolium bromide] (MTT) and lactate dehydrogenase (LDH) assays.

Results: This study demonstrated that butanol fraction had the highest antioxidant activity among all solvent fractions from methanolic extract E. annuus leaf. Butanol fraction had the highest total phenolic contents (396.49 $\mathrm{mg}$ of GAE/g). Caffeic acid, an isolated active compound from butanol fraction, showed dose-dependent in vitro antioxidant activity. Moreover, neuronal cell protection against oxidative stress induced cytotoxicity was also demonstrated.
\end{abstract}

Conclusion: Erigeron annuus leaf extracts containing caffeic acid as an active compound have antioxidative and neuroprotective effects on neuronal cells.

\section{Background}

Oxidative stress refers to the imbalance between the production and removal of reactive oxygen species (ROS). Due to the reaction between ROS and macromolecules, generation of ROS can lead to damage or death of cells in various tissues [1]. Brain tissue is most vulnerable to oxidative stress due to its high glucose metabolism rate and low antioxidant defense enzyme level [2]. Natural antioxidants are promising candidates of chemopreventive agents for treating neurodegenerative diseases such as Alzheimer's disease (AD), cerebral ischemia and Parkinson's disease (PD) [3].

About 18 million people in the world suffer from AD, the number of which is expected to reach 34 million by $2025[4,5]$. Characterized by loss of memory and cognition, $\mathrm{AD}$ is one of the most serious health threats in aging societies. In $\mathrm{AD}$ patients, who have high sensitivity

\footnotetext{
* Correspondence: hjher@gnu.ac.kr

${ }^{2}$ Department of Food Science and Technology, Institute of Agriculture and

Life Science, Gyeongsang National University, Jinju 660-701, Korea

Full list of author information is available at the end of the article
}

to ROS, accumulated intracellular hydrogen peroxide $\left(\mathrm{H}_{2} \mathrm{O}_{2}\right)$ induces membrane lipid peroxidation, and sometimes even caspases [4]. Brains of patients suffering from $\mathrm{AD}$ are subjected to an increase of free radical damage due to oxidative stress [6]. Many phenolics protect neuronal cells from oxidative stress induced by ROS or amyloid- $\beta$ protein which may be related to the pathogenesis of AD [7]. Some phytochemicals from natural plant sources such as fruits and vegetable may reduce the risk of $\mathrm{AD}$ because of their antioxidant properties [8]. Epidemiological observation shows that the increase of antioxidant uptake is inversely correlated to the risk of $\mathrm{AD}$ incidence [9].

We focus on various fractions of the methanolic extract of Erigeron annuus (Yinianpeng) leaf for antioxidant and neuronal cell protective potentials. E. annuus, which belongs to the Compositae family, is widely distributed in urban and rural areas of Korea and China. E. annuus has been used in Chinese medicine for treating indigestion, enteritis, epidemic hepatitis and hematuria [10]. Phytochemicals from this plant
Ciomed Central

() 2011 Jeong et al; licensee BioMed Central Ltd. This is an Open Access article distributed under the terms of the Creative Commons Attribution License (http://creativecommons.org/licenses/by/2.0), which permits unrestricted use, distribution, and reproduction in any medium, provided the original work is properly cited. 
have been isolated and reported such as $\gamma$-pyranone derivatives, flavonoids, triterpenoids [11], phenolic derivatives [12,13], cyclopentenone derivatives [14] and sesquiterpenenes [15]. E. annuus possesses antioxidant [16] antiglycation and rat lens aldose reductase inhibition activities [17]. Moreover, E. annuus is cytoprotective [18] and antidiabetic [19]. However, little is known about E. annuus' neuronal cell protective effects against oxidative stress.

This study examines antioxidant and neuroprotective effects of all fractions of the methanolic extract of Erigeron annuus leaf and identifies active compounds of the extract.

\section{Methods}

\section{Chemicals}

RPMI 1640 medium, fetal bovine serum (FBS), horse serum (HS) were purchased from Gibco BRL (USA). Unless specified otherwise, all materials used in this study were purchased from Sigma Chemical (USA), including 2,2-azino-bis(3-ethylbenz thiazoline-6-sulfonic acid diammonium salt) $\left[\left(\mathrm{NH}_{4}\right)_{2} \mathrm{ABTS}\right]$, potassium persulfate, 2,4,6-tripyridyl-S-triazine (TPTZ), vitamin C, thiobarbituric acid, ferrous sulfate $\left(\mathrm{FeSO}_{4}\right)$, hydrogen peroxide $\left(\mathrm{H}_{2} \mathrm{O}_{2}\right)$, dimethyl sulfoxide (DMSO), penicillin, streptomycin, 2',7'-dichlorofluorescein diacetate (DCFDA), 3-[4,5-dimethythiazol-2-yl]-2,5-diphenyl tetrazolium bromide (MTT) assay kit and lactate dehydrogenase (LDH) assay kit.

\section{Plant extraction}

Erigeron annuus leaves were collected from Jinju, Korea in September 2009 and were authenticated by the Institute of Agriculture and Life Sciences, Gyeongsang National University where voucher specimens were deposited. Samples were washed with running tap water before chopped into pieces. They were then oven-dried at $40^{\circ} \mathrm{C}$ for two days and ground to powder which was stored at $-20^{\circ} \mathrm{C}$ until use. Organic solvent fractions of the methanolic extract of $E$. annuus were obtained as follows. Powder of E. annuus (50 g) was suspended and extracted with $500 \mathrm{ml}$ of methanol at $70^{\circ} \mathrm{C}$ for two hours. The extracts were filtered through Whatman No. 2 filter paper (Whatman International, UK) and evaporated to dryness. The crude extracts were then extracted successively with chloroform, butanol and water to yield the corresponding chloroform (37.13\%), butanol (15.19\%) and water (47.68\%) fractions.

\section{Determination of total phenolics}

Total phenolics were determined by spectrophotometric analysis [20]. Total phenolics in organic solvent fractions of $E$. annuus extracts were expressed as milligrams of gallic acid equivalents (mg GAE/g) of sample.

\section{ABTS radical scavenging activity}

2,2-azino-bis(3-ethylbenz thiazoline-6-sulfonic acid diammonium salt) $\left[\left(\mathrm{NH}_{4}\right)_{2} \mathrm{ABTS}\right]$ was dissolved in water to make a concentration of $7 \mathrm{mM}$. ABTS ${ }^{+}$was produced through reacting the ABTS stock solution with 2.45 $\mathrm{mM}$ potassium persulfate (final concentration) and allowing the mixture to stand in the dark at room temperature for 12-16 hours before use. For the study of samples, the ABTS stock solution with $2.45 \mathrm{mM}$ potassium persulfate was diluted with phosphate-buffered saline $5 \mathrm{mM}, \mathrm{pH} 7.4$ to obtain an absorbance of 0.70 at 734 $\mathrm{nm}$. After addition of $980 \mu \mathrm{l}$ of diluted ABTS to $20 \mu \mathrm{l}$ of sample, the absorbance reading was taken five minutes after the initial mixing [20]. Vitamin $C$ was used as the positive control. This activity was measured as percent ABTS scavenging calculated as \% ABTS scavenging activity $=\left[1-\left(\mathrm{A}_{\text {sample }}-\mathrm{A}_{\text {control }}\right) / \mathrm{A}_{\text {control }}\right] \times 100$

\section{FRAP}

The ferric reducing antioxidant power (FRAP) assay was developed by Jeong et al. [20]. Briefly, $1.5 \mathrm{ml}$ of working, pre-warmed $37^{\circ} \mathrm{C}$ FRAP reagent (10 volumes $300 \mathrm{mM} / \mathrm{L}$ acetate buffer, pH3.6 + one volume of $10 \mathrm{mM} / \mathrm{L}$ 2,4,6tripyridyl-S-triazine in $40 \mathrm{mM} / \mathrm{L} \mathrm{HCl}+$ one volume of $20 \mathrm{mM} / \mathrm{L} \mathrm{FeCl}_{3}$ ) was mixed with $50 \mu \mathrm{l}$ of the test sample and standards. The mixture was vortexed and read against a reagent (blank at a predetermined time after sample-reagent mixing) at $593 \mathrm{~nm}$ absorbance. The test was performed at $37^{\circ} \mathrm{C}$ and the window of $0-4$ minute reaction time was used. Vitamin $\mathrm{C}$ was used as the positive control. Reduction of the ferric-tripyridyltriazine to the ferrous complex formed an intense blue color which was measured at a wavelength of $593 \mathrm{~nm}$. Intensity of the color is related to the amount of antioxidant reductants in the samples.

\section{Identification and quantification of active compounds}

The most active fraction was determined with various assays. After assays, the butanol fraction was divided into 32 sub-fractions (BF1-BF32) by column chromatography with silica-gels (230-400 mesh, Merck, Germany) eluted with chloroform/methanol (gradient elution: 99/1 to $1 / 1$ ). Compound 1 as an active compound was isolated and purified from sub-fraction BF17 with high performance liquid chromatograph (HPLC) on an Agilent instrument (1100 series, USA) with a $250 \mathrm{~mm} \times 4.6$ $\mathrm{mm}, 5 \mu \mathrm{m} \mathrm{C}_{18}$ column (Shiseido, Japan). Mobile phase consisted of acetonitrile: acetic acid: methanol: water $(113: 5: 20: 862, \mathrm{v} / \mathrm{v} / \mathrm{v} / \mathrm{v})$. Flow rate was $1.0 \mathrm{ml}$ per minute with an injection volume of $20 \mu \mathrm{l}$. Compounds were detected through monitoring the elution at $280 \mathrm{~nm}$. Compound 1 was purified by preparative TLC with chloroform/methanol (4:1, v/v). NMR data including ${ }^{1} \mathrm{H}$ and ${ }^{13} \mathrm{C}$ spectra of Compound 1 dissolved in $\mathrm{CD}_{3} \mathrm{OD}$ 
were determined with a $500 \mathrm{MHz}$ spectrometer (Bruker, Germany).

\section{Inhibition of lipid peroxidation assay with mouse brain homogenates}

This assay was carried out according to the method described by Chang et al. [21]. The brain of young adult male $\mathrm{Balb} / \mathrm{c}$ mice were dissected and homogenized in ice-cold Tris- $\mathrm{HCl}$ buffer $(20 \mathrm{mM}, \mathrm{pH} 7.4)$ to produce a 1/10 homogenate. The homogenate was centrifuged (Combi-514R, Hanil Co. Ltd., Korea) at $12,000 \times g$ for 15 minutes at $4^{\circ} \mathrm{C}$. Aliquots $(0.1 \mathrm{ml})$ of the supernatant were incubated with the test samples in the presence of $10 \mu \mathrm{M} \mathrm{FeSO}_{4}(0.1 \mathrm{ml})$ and $0.1 \mathrm{mM}$ vitamin $\mathrm{C}(0.1 \mathrm{ml})$ at $37^{\circ} \mathrm{C}$ for one hour. The reaction was terminated by the addition of $0.1 \mathrm{ml}$ trichloroacetic acid (TCA) (28\%, $\mathrm{w} / \mathrm{v})$ and $0.3 \mathrm{ml}$ thiobarbituric acid (TBA) $(1 \%, \mathrm{w} / \mathrm{v})$ in succession; the solution was then heated at $100^{\circ} \mathrm{C}$. After 15 minutes, the color of the MDA-TBA complex was measured at $532 \mathrm{~nm}$. A well-known antioxidant, namely (+)-Catechin, was used as positive control. Three replicates were prepared for each test sample. The inhibition ratio (\%) was calculated as follows.

$$
\% \text { inhibition }=\left[1-\left(\mathrm{A}_{\text {sample }}-\mathrm{A}_{\text {control }}\right) / \mathrm{A}_{\text {control }}\right] \times 100
$$

\section{Neuronal cell culture}

PC12 cells respond reversibly to nerve growth factor (NGF) by induction of the neuronal phenotype. PC12 cells (KCLB 21721, Korea Cell Line Bank, Korea) were propagated in Rosewell Park Memorial Institute (RPMI) 1640 medium containing 10\% fetal bovine serum, 25 mM 4-(2-hydroxylethyl)-1-piperazineethanesulfonic acid (HEPES), $25 \mathrm{mM}$ sodium bicarbonate, 50 units/ml penicillin and $100 \mu \mathrm{g} / \mathrm{ml}$ streptomycin.

\section{Measurement of intracellular oxidative stress}

Levels of intracellular ROS were determined by 2',7'dichlorofluorescein diacetate (DCF-DA) assay [22]. Briefly, cells $\left(10^{4}\right.$ cells/well on 96 -well $)$ were treated for $10 \mathrm{~min}$ utes with the indicated concentrations of the caffeic acid isolated from butanol fraction of E. annuus or vitamin C. The cells were then treated with or without $200 \mu \mathrm{M}$ $\mathrm{H}_{2} \mathrm{O}_{2}$ for two hours. At the end of the treatment, cells were incubated in the presence of $50 \mu \mathrm{M}$ DCF-DA in phosphate buffered saline (PBS). Fluorescence was then quantified on a TECAN fluorometer (SER-NR 94572, USA) with $485 \mathrm{~nm}$ excitation and $530 \mathrm{~nm}$ emission filters.

\section{Protective effect on oxidative stress}

MTT reduction assay was determined with an in vitro toxicology assay kit (TOX-1, Sigma Co, USA). Neuronal PC12 cells were plated at a density of $10^{6}$ cells/well on 96-well plates in $100 \mu \mathrm{l}$ of RPMI. The cells were preincubated with caffeic acid isolated from butanol fraction of E. annuus for 48 hours before $\mathrm{H}_{2} \mathrm{O}_{2}(200 \mu \mathrm{M})$ was added. The cells were treated with or without $\mathrm{H}_{2} \mathrm{O}_{2}$ for two hours. The amount of MTT formazan product was determined through measuring absorbance with a microplate reader (680, Bio-Rad, Japan) at a test wavelength of $570 \mathrm{~nm}$ and a reference wavelength of $690 \mathrm{~nm}$.

Neuronal PC12 cells were precipitated through centrifugation (Combi-514R, Hanil Co. Ltd., Seoul, Korea) at $250 \times g$ for four minutes at room temperature, $100 \mu \mathrm{l}$ of the supernatants was transferred into new wells. LDH was determined with an in vitro toxicology assay kit (TOX-7, Sigma Co, USA). Damage of the plasma membrane was evaluated through measuring the amount of the intra-cellular enzyme $\mathrm{LDH}$ released into the medium.

\section{Statistical analysis}

All data were expressed as mean $\pm \mathrm{SD}(n=3)$. Data were analyzed with one-way of variance (ANOVA) and Duncan's multiple range test in SAS (8.2 version, SAS Institute, USA).

\section{Results and discussion}

Total phenolics and antioxidant activities of various fractions of the methanolic extract of $E$. annuus

Expressed as gallic acid equivalent (GAE), the total phenolics in various solvent fractions of the methanolic extract of $E$. annuus were determined according to the Folin-Ciocalteu method [20]. Total phenolic contents in butanol fraction were the highest (396.49 mg of GAE/g), followed by water fraction (241.87 $\mathrm{mg}$ of $\mathrm{GAE} / \mathrm{g}$ ) and chloroform fraction (107.34 mg of GAE/g) (Table 1). Many studies suggested that antioxidant activity of plants was likely related to redox properties of their phenolics behavior ( $e g$ as reducing agents, hydrogen donors and singlet oxygen quenchers) [23].

The ABTS radical scavenging activities of the various fractions of the methanolic extract of E. annuus were

Table 1 Total phenolic contents and $\mathrm{EC}_{50}$ values (ABTS free radical scavenging assay) of their derived fractions of the methanolic extract of $E$. annuus leaf

\begin{tabular}{ccc}
\hline Solvent fractions & $\mathrm{EC}_{\mathbf{5 0}}(\boldsymbol{\mu g} / \mathbf{m l})$ & $\begin{array}{c}\text { Total phenolics } \\
(\mathbf{m g} \text { of } \mathrm{GAE} / \mathbf{g})\end{array}$ \\
\hline Chloroform & 528.81 & $107.34 \pm 1.87^{*}$ \\
Butanol & 250.00 & $396.49 \pm 2.18$ \\
Water & 304.76 & $241.87 \pm 4.06^{* *}$ \\
Vitamin C & 47.97 & - \\
\hline
\end{tabular}

$\mathrm{EC}_{50}: 50 \%$ effective concentration.

Results are presented as mean \pm SD of three independent experiments; the letters (a-d) indicate statistically significant differences $(* P=0.025$, ** $P=0.047)$. 


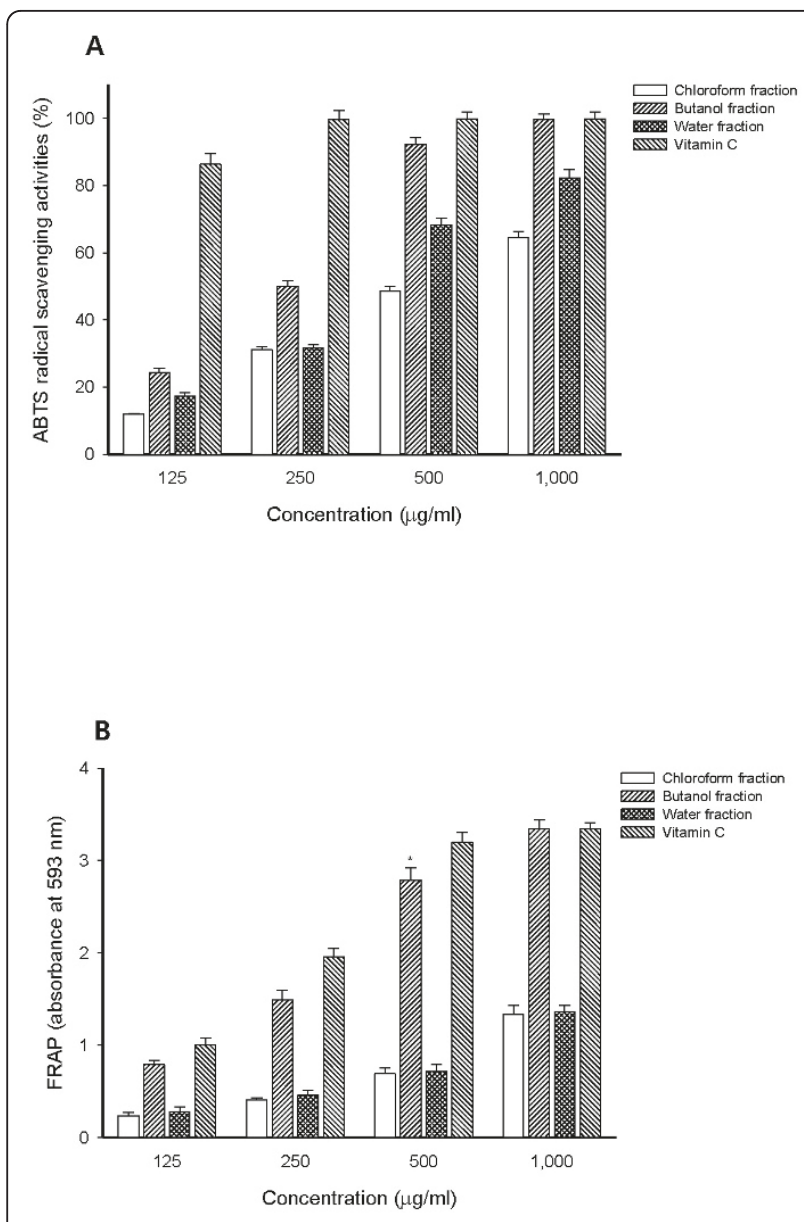

Figure 1 (A) ABTS radical scavenging activities and (B) FRAP of fractions from the methanolic extract of $E$. annuus leaf. Results are presented as mean \pm SD of three independent experiments. (B) * $P=0.022$, vs. positive control.

estimated through comparing the percentage inhibition of the formation of ABTS radicals by the various fractions and that of vitamin C. As shown in Figure 1A, the highest activity was observed in the butanol fraction and the water fraction also showed good inhibitory effects. In the presence of the $1,000 \mu \mathrm{g} / \mathrm{ml}$ test sample, the ABTS radical inhibition of organic solvent fractions decreased in the following order: butanol fraction $(99.69 \%)>$ water fraction $(82.32 \%)>$ chloroform fraction $(64.48 \%)$. Vitamin C (positive control), a well-known natural antioxidant, showed $99.86 \%$ inhibition on the ABTS radical at a concentration of $500 \mu \mathrm{g} / \mathrm{ml}$ (Figure 1A).

The $\mathrm{EC}_{50}$ value of vitamin $\mathrm{C}$, chloroform, butanol and water fractions were 47.97, 528.81, 250.00 and 304.76 $\mu \mathrm{g} / \mathrm{ml}$ respectively (Table 1 ). Kim and Kim [16] found that $50 \%$ ethanol extract of whole E. annuus possessed significant ABTS radical scavenging activity with an $\mathrm{EC}_{50}$ value of $125 \mu \mathrm{g} / \mathrm{ml}$.
Another antioxidant activity was studied through ferric reducing antioxidant power assay. Samples were used in a redox-linked reaction where the antioxidants in the sample acted as oxidants.. As shown in Figure $1 \mathrm{~B}$, the ferric reducing antioxidant power of various fractions of methanolic extract of $E$. annuus at $1,000 \mu \mathrm{g} / \mathrm{ml}$ were as follows: butanol fraction $($ absorbance value $=3.34)>$ water fraction (absorbance value $=1.36$ ) $>$ chloroform fraction (absorbance value $=1.34)$. Ferric reducing antioxidant power of the butanol fraction was the highest among all fractions and increased linearly with increasing concentrations. These results agreed to another study with similar correlations between total polyphenols and antioxidant activity [24].

\section{Identification and quantification of caffeic acid as an active compound}

Among the column fraction of butanol fraction, BF17 had an excellent ABTS radical scavenging activity with an $\mathrm{EC}_{50}$ value of $112.26 \mu \mathrm{g} / \mathrm{ml}$. To find out its active component, we isolated and identified Compound 1 as an active compound from BF17 using HPLC (retention time $=11.36$ minutes) (Figure 2) and NMR spectrometry. Compound 1 was characterized as a caffeic acid with following characteristics: yellow amorphous solid: ESIMS $m / z$ 180; ${ }^{1} \mathrm{H}$ NMR $\left(\mathrm{CD}_{3} \mathrm{OD}, 500 \mathrm{MHz}\right) \delta: 7.55$ $(1 \mathrm{H}, \mathrm{d}, \mathrm{J}=15.9 \mathrm{~Hz}, \mathrm{H}-7), 7.07(1 \mathrm{H}, \mathrm{d}, \mathrm{J}=2.0 \mathrm{~Hz}, \mathrm{H}-$ 2), 6.95 (1 H, dd, J = 8.2, $2.0 \mathrm{~Hz}, \mathrm{H}-6), 6.81$ (1 H, d, J = 8.2, H-5), 6.24 (1 H, d, J = $15.9 \mathrm{~Hz}, \mathrm{H}-8) ;{ }^{13} \mathrm{C}-\mathrm{NMR}$ $\left(\mathrm{CD}_{3} \mathrm{OD}, 125 \mathrm{MHz}\right) \delta 171.6$ (C-9), 149.8 (C-4), 147.6 (C-7), 147.2 (C-3), 128.3 (C-1), 123.4 (C-6), 117.0 (C-5), 116.0 (C-8), 115.7 (C-2) (Figure 3). Spectral data of the isolated caffeic acid were in good agreement with the published values of standards [25]. HPLC quantification revealed that $3.68 \mu \mathrm{g}$ of caffeic acid was in $1 \mathrm{mg}$ of butanol fraction.

\section{Inhibition of lipid peroxidation and intracellular accumulation of ROS by caffeic acid}

Inhibition of lipid peroxidation assay confirmed antioxidant activities of caffeic acid isolated from butanol fraction of E. annuus on both ferric ion and vitamin Cinduced lipid peroxidation on mouse brain homogenates. Caffeic acid suppressed lipid peroxidation on mouse brain homogenates (Figure 4A). Caffeic acid showed less effectiveness than (+)-catechin at all concentrations; more than $50 \%$ of inhibitory activity of lipid peroxidation was observed at the concentration of 50 $\mu \mathrm{g} / \mathrm{ml}$. However, caffeic acid had an $\mathrm{EC}_{50}$ value of 38.43 $\mu \mathrm{g} / \mathrm{ml}$, compared to $(+)$-catechin $(31.17 \mu \mathrm{g} / \mathrm{ml})$. Previous studies indicated that caffeic acid had excellent antioxidant and neuroprotective effects [26]. These results suggested a potential use of the crude extract of $E$. annuus 

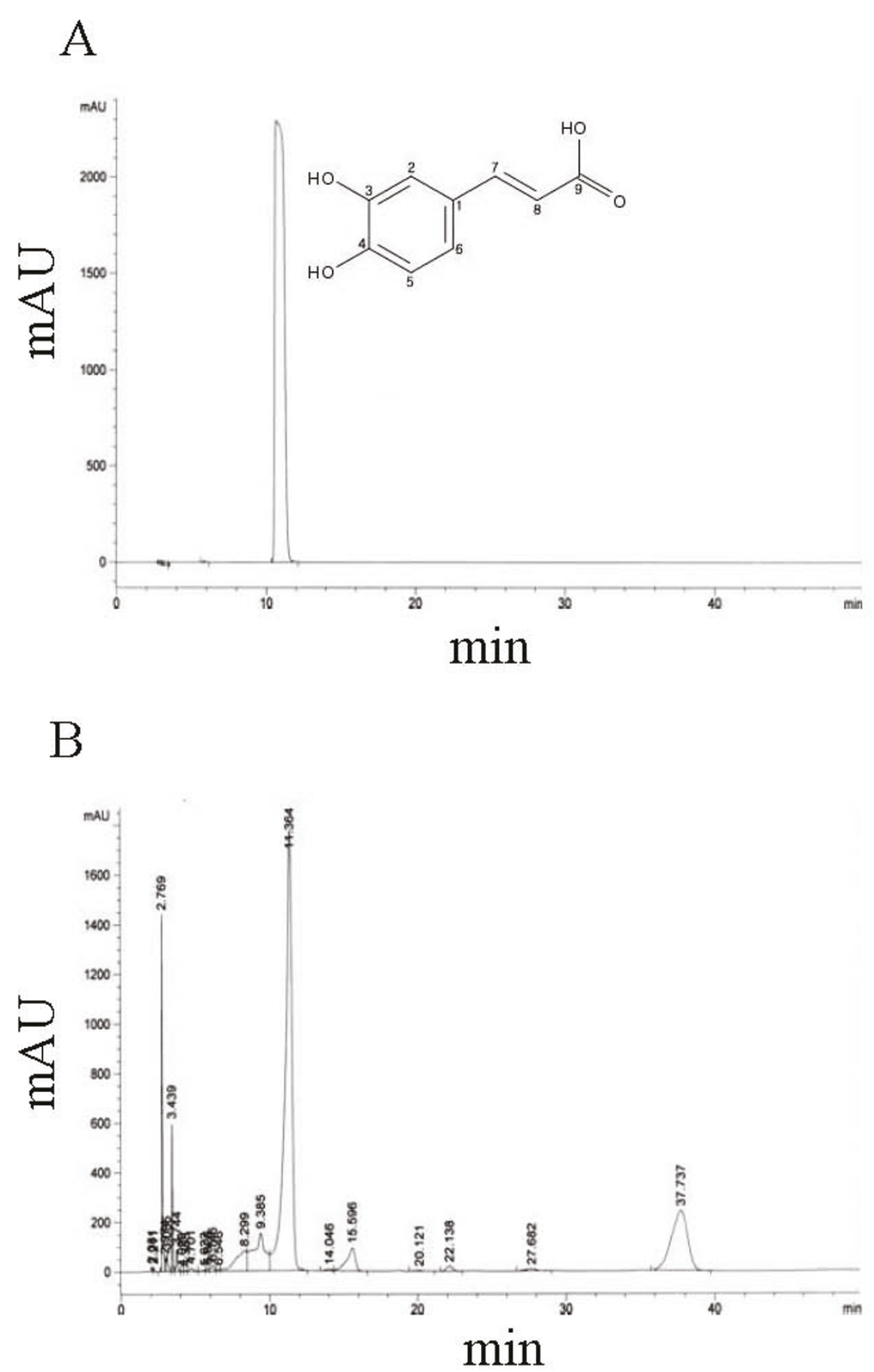

Figure 2 (A) HPLC chromatogram of commercial standard and (B) caffeic acid isolated from the butanol fraction of $E$. annuus leaf.

as well as the isolated compounds for treating neurodegenerative diseases such as AD.

To examine intracellular accumulation of ROS in PC12 cells used as neuronal cell model, we used 2',7'-dichlorofluorescein diacetate (DCFH-DA) probe which is freely permeable across cell membrane. DCFH-DA was hydrolyzed by cytosolic esterases to non-fluorescent dichlorofluorescein (DCFH). DCFH that interacted with ROS was oxidized to a highly fluorescent substance, namely 2',7'dichlorofluorescein (DCF). Exposure of PC12 cells to 
A

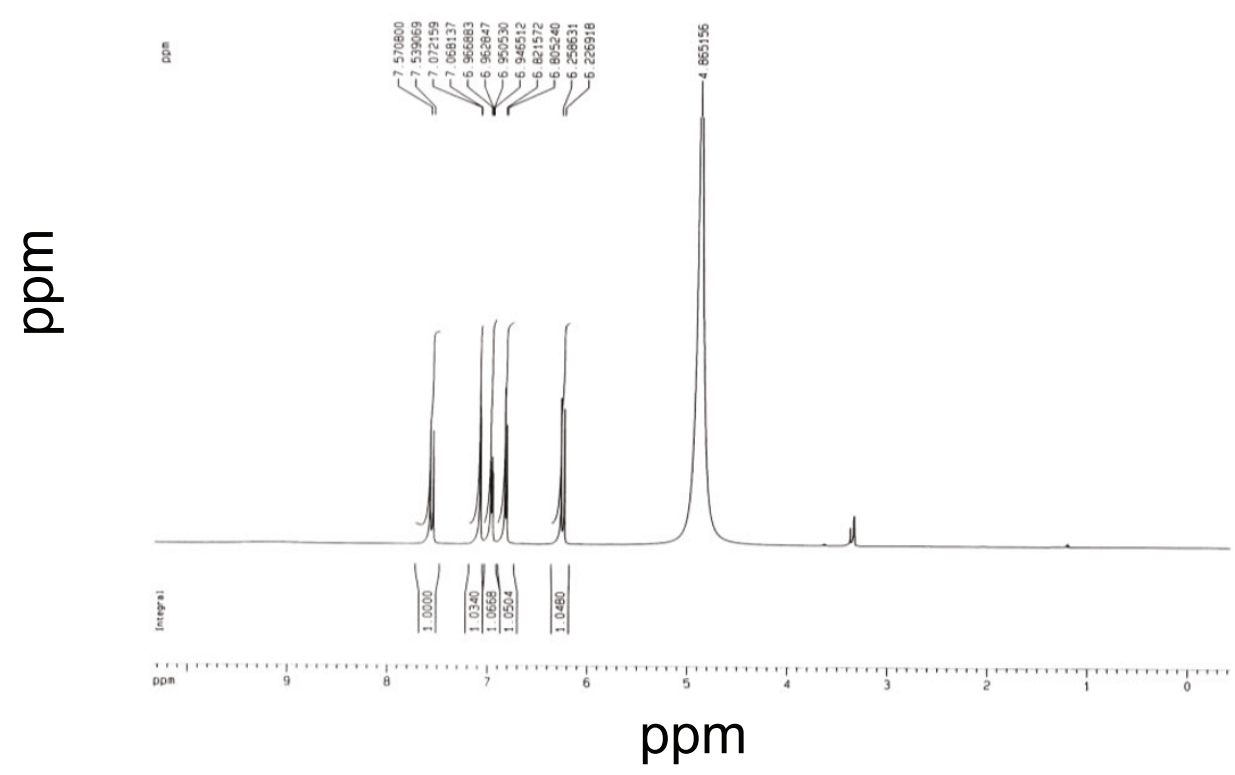

B

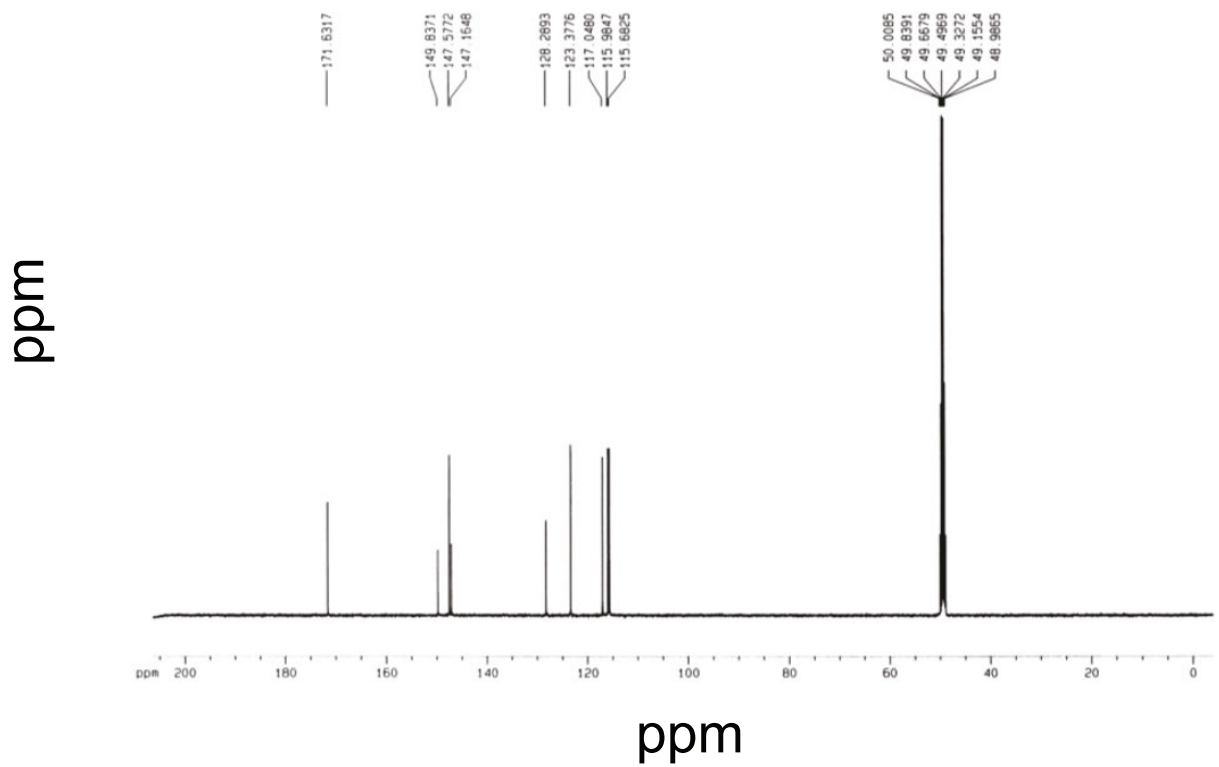

Figure 3 (A) ${ }^{1} \mathrm{H}$-NMR and (B) ${ }^{13} \mathrm{C}$-NMR spectrum of caffeic acid isolated from the butanol fraction of $E$. annuus leaf.

$\mathrm{H}_{2} \mathrm{O}_{2}$ for two hours resulted in a $132.28 \%$ increase of the ROS levels compared to control (Figure 4B). Pretreatment of PC12 cells by caffeic acid significantly prevented them from intracellular ROS accumulation in comparison to the PC12 cells treated only with $\mathrm{H}_{2} \mathrm{O}_{2}$ (control). Vitamin $\mathrm{C}$ is one of the naturally occurring major nutrients with antioxidant activity. PC12 cells had significantly lower oxidative stress than PC12 cells with treatments of $\mathrm{H}_{2} \mathrm{O}_{2}$ only (Figure $4 \mathrm{~B}$ ). This result suggested that caffeic acid isolated from butanol fraction of $E$. annuus with antioxidant activity might play an important role in reducing the oxidative stress. 


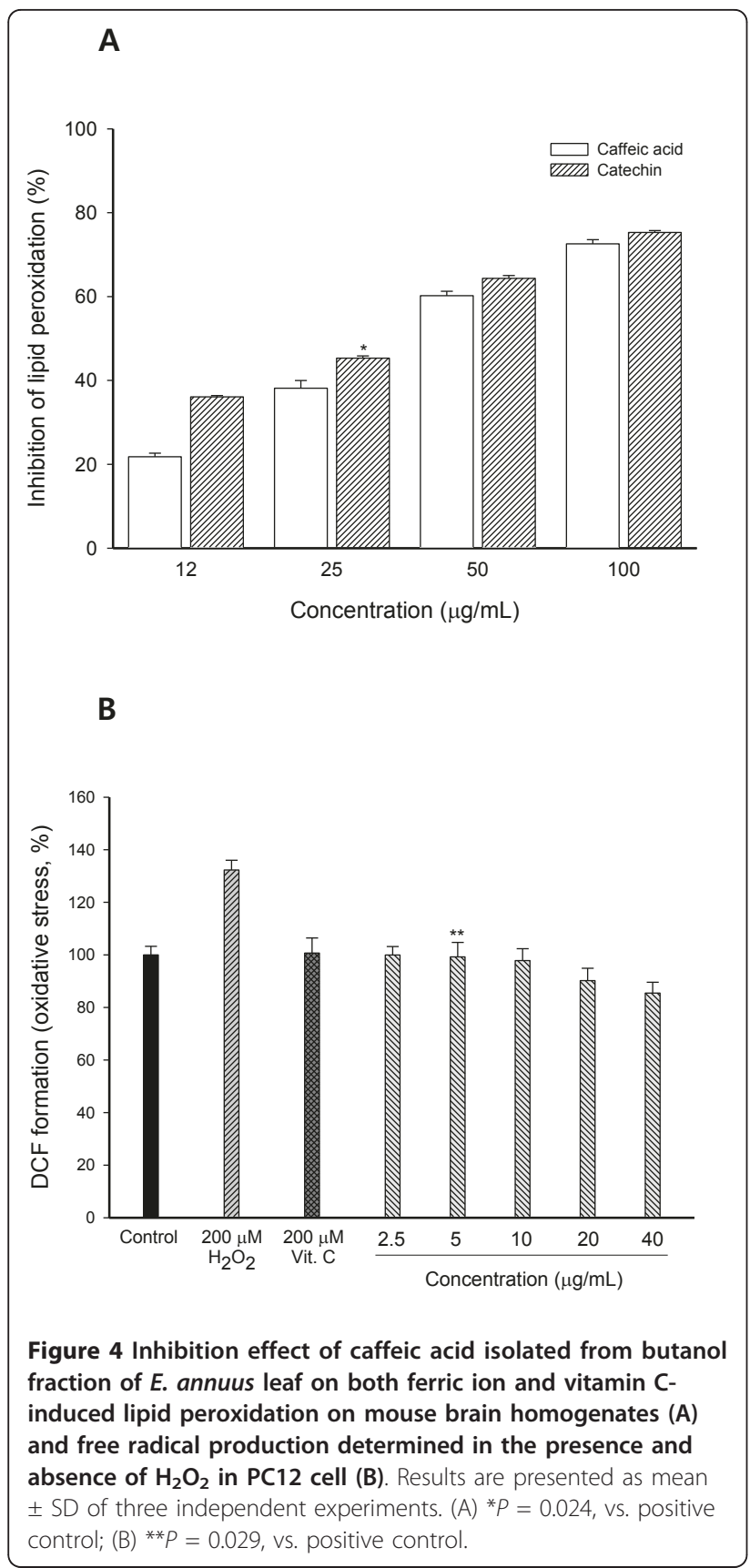

Protection of $\mathrm{PC} 12$ cells treated with by $\mathrm{H}_{2} \mathrm{O}_{2}$ caffeic acid As shown in Figure 5A, the protection of PC12 cells increased dose-dependently with the concentrations at $2.5-40 \mu \mathrm{g} / \mathrm{ml}$ and reached the best protection ie $148 \%$ of control group, at $40 \mu \mathrm{g} / \mathrm{ml}$. Our results indicated that caffeic acid protected neuronal PC12 cells against $\mathrm{H}_{2} \mathrm{O}_{2}$ induced neurotoxicity.

As the neuronal plasma membrane is sensitive to oxidative stress, we measured the LDH activity released from apoptotic PC12 cells into the medium. A quantitative analysis of LDH activity can determine the

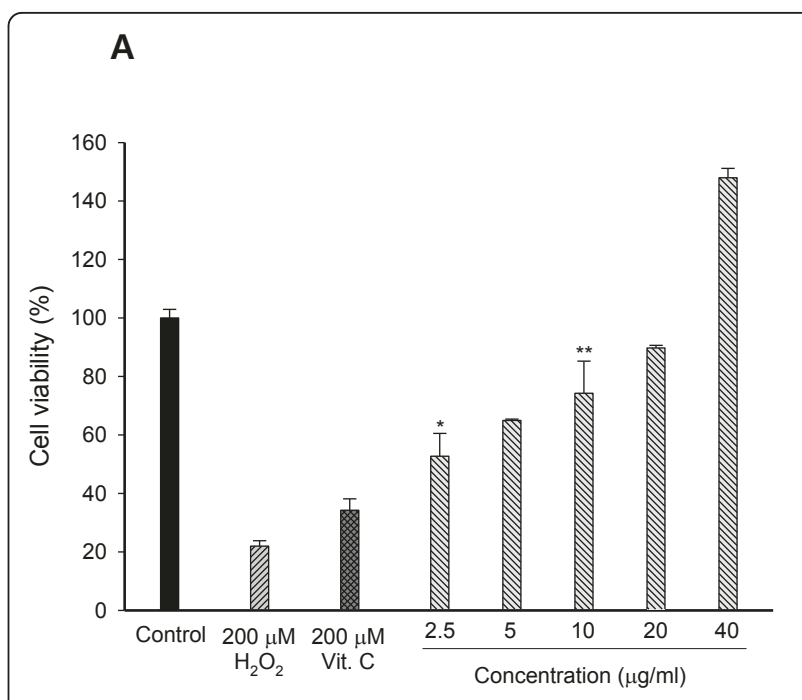

B

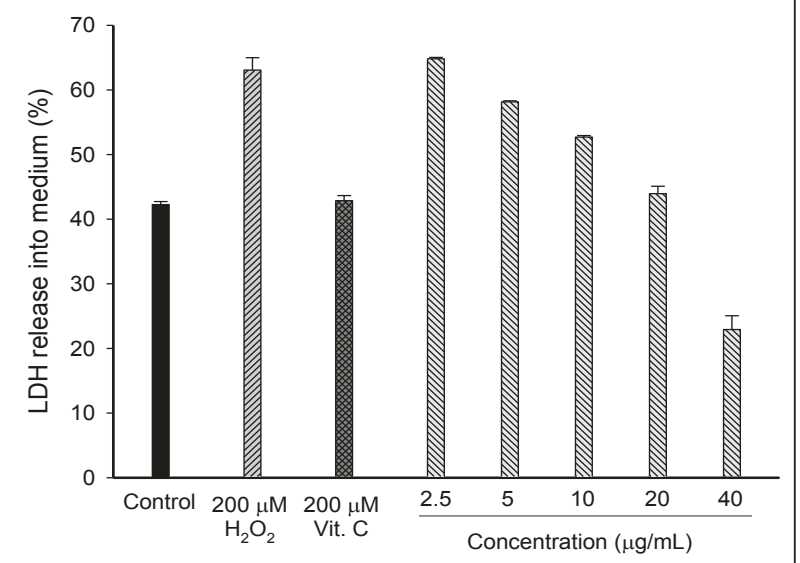

Figure 5 (A) Protective effects of caffeic acid isolated from $E$. annuus leaf on hydrogen peroxide-induced neurotoxicity and (B) membrane damage in PC12 cell system. PC12 cells were pretreated for 48 hours with various concentrations. After 48 hours, cells were treated with $200 \mu \mathrm{M} \mathrm{H}_{2} \mathrm{O}_{2}$ for two hours. Results are presented as mean \pm SD of three independent experiments. (A) $* P$ $=0.037,{ }^{* *} P=0.046$, vs. positive control.

percentage (\%) of dead cells. Inhibition rates of caffeic acid isolated from $E$. annuus against $\mathrm{H}_{2} \mathrm{O}_{2}$-induced membrane damage at different concentrations were shown in Figure 5B. Treatment with $200 \mu \mathrm{M} \mathrm{H}_{2} \mathrm{O}_{2}$ caused an increase in LDH release into the medium (63.08\%). Pretreatment with caffeic acid caused an inhibitory effect on LDH release with the highest inhibition (22.92\%) at $40 \mu \mathrm{g} / \mathrm{ml}$.

The phenolic hydroxyl groups of caffeic acid, particularly the ortho-hydroxy phenol group, were suggested to be a stable oxidation intermediate, the ortho-hydroxyphenoxyl radical that could quench free radicals [27]. These findings 
suggested that the strong antioxidant activities of caffeic acid decreased the $\mathrm{H}_{2} \mathrm{O}_{2}$-induced oxidative stress Oxidative damage is one of the neurotoxic mechanisms induced by $\mathrm{H}_{2} \mathrm{O}_{2}$. Early depletion of antioxidant compounds such as glutathione was considered important to the development of AD pathology [28]. Therefore, antioxidant activities of caffeic acid may provide neuroprotection against $\mathrm{H}_{2} \mathrm{O}_{2}$-induced toxicity. Future investigation is warranted to elucidate the cellular mechanism for the neuroprotection of $E$. annuus leaf phenolics, caffeic acid in particular.

\section{Conclusion}

The butanol fraction had the highest antioxidant activity as revealed in the ABTS and FRAP assays. Moreover, caffeic acid decreased oxidative stress induced by $\mathrm{H}_{2} \mathrm{O}_{2}$ and demonstrated very strong antioxidant activities and neuronal cell protective effects. E. annuus leaf may be used as an anti-oxidant and chemopreventive agent to treat neurodegenerative disorders such as AD.

\section{Abbreviations}

ABTS: 2,2-azino-bis(3-ethylbenz thiazoline-6-sulfonic acid); FRAP: ferric reducing antioxidant power; MT: 3-[4,5-dimethythiazol-2-yl]-2,5-diphenyl tetrazolium bromide; LDH: lactate dehydrogenase; ROS: reactive oxygen species; AD: Alzheimer's disease; PD: Parkinson's disease; $\mathrm{H}_{2} \mathrm{O}_{2}$ : hydrogen peroxide; TCA: trichloroacetic acid; TBA: thiobarbituric acid; MDA: malondialdehyde; NGF: nerve growth factor; DCF-DA: 2',7'-dichlorofluorescein diacetate; PBS: phosphate buffered saline

\section{Acknowledgements}

This work was partially supported by the National Research Foundation of Korea Grant funded by the Korean Government (KRF-2008-521-F00074 and NRF-2009-351-F00028) and the Technology Development Program for Regional Industry of Ministry of Knowledge Economy, Republic of Korea (2009-70007068)

\section{Author details}

${ }^{1}$ Department of Food Science and Biotechnology, Institute of Life Sciences and Resources, Kyung Hee University, Yongin 446-701, Korea. ${ }^{2}$ Department of Food Science and Technology, Institute of Agriculture and Life Science, Gyeongsang National University, Jinju 660-701, Korea. ${ }^{3}$ Department Special Purpose Trees, Korea Forest Research Institute, Suwon 441-847, Korea.

\section{Authors' contributions}

$\mathrm{CHJ}$ and $\mathrm{HJH}$ designed the study. $\mathrm{CHJ}, \mathrm{GNC}$ and HRJ conducted the experiments, analyzed the data and drafted the manuscript. DOK revised the manuscript. UL helped conduct the experiments. All authors read and approved the final version of the manuscript

\section{Competing interests}

The authors declare that they have no competing interests.

Received: 16 February 2011 Accepted: 24 June 2011

Published: 24 June 2011

\section{References}

1. Cui K, Luo X, Xu K, Ven Murthy MR: Role of oxidative stress in neurodegeneration: recent developments in assay methods for oxidative stress and nutraceutical antioxidants. Prog Neuropsychopharmacol Biol Psychiatry 2004, 28:771-799.

2. Olanow CW: A radical hypothesis for neurodegeneration. Trends NeurosCi 1993, 16:439-444
3. Zhang HY, Tang XC: Huperzine $B$, a novel acetylcholinesterase inhibitor, attenuates $\mathrm{H}_{2} \mathrm{O}_{2}$ induced injury in PC12 cells. Neurosci Lett 2000 292:41-44.

4. Valencia A, Morán J: Reactive oxygen species induce different cell death mechanisms in cultured neurons. Free Radic Biol Med 2004, 36:1112-1125.

5. Mount C, Downton C: Alzheimer disease: progress of profit? Nat Med 2006, 12:780-784.

6. Markesbery WR, Carney JM: Oxidative alterations in Alzheimer's disease. Brain Pathol 1999, 9:133-146.

7. Kou MC, Yen JH, Hong JT, Wang CL, Lin CW, Wu MJ: Cyphomandra betacea Sendt. phenolics protect LDL from oxidation and PC12 cells from oxidative stress. Lebenson Wiss Technol 2009, 42:458-463.

8. Youdim KA, Joseph JA: A possible emerging role of phytochemicals in improving age-related neurological dysfunctions: a multiplicity of effects. Free Radic Biol Med 2001, 30:583-594

9. Grundman M, Grundman M, Delaney P: Antioxidant strategies for Alzheimer's disease. Proc Nutr Soc 2002, 61:191-202.

10. Yoo NH, Jang DS, Yoo JL, Lee YM, Kim YS, Cho JH, Kim JS: Erigeroflavanone, a flavanone derivative from the flowers of Erigeron annuus with protein glycation and aldose reductase inhibitory activity. J Nat Prod 2008, 71:713-715.

11. Hashidoko $Y$ : Pyromeconic acid and its glucosidic derivatives from leaves of Erigeron annuus, and the siderophile activity of pyromeconic acid. Biosci Biotechnol Biochem 1995, 59:886-890.

12. Oh H, Lee S, Lee HS, Lee DH, Lee SY, Chung HT, Kim TS, Kwon TO: Germination inhibitory constituents from Erigeron annuus. Phytochemistry 2002, 61:175-179.

13. Li X, Pan J, Gao K: Gamma-pyranone derivatives and other constituents from Erigeron annuus. Pharmazie 2006, 61:474-477.

14. lijima T, Yaoita Y, Kikuchi M: Two new cyclopentenone derivatives and a new cyclooctadienone derivative from Erigeron annuus (L.) PERS., Erigeron philadelphicus L., and Erigeron sumatrensis RETZ. Chem Pharm Bull 2003, 51:894-896.

15. Li X, Yang M, Han YF, Gao K: New sesquiterpenes from Erigeron annuus. Planta Med 2005, 71:268-272.

16. Kim HY, Kim K: Protein glycation inhibitory and antioxidative activities of some plant extracts in vitro. J Agric Food Chem 2003, 51:1586-1591.

17. Jang DS, Yoo NH, Lee YM, Yoo JL, Kim YS, Kim JS: Constituents of the flowers of Erigeron annuus with inhibitory activity on the formation of advanced glycation end products (AGEs) and aldose reductase. Arch Pharm Res 2008, 31:900-904.

18. Kim OS, Kim YS, Jang DS, Yoo NH, Kim JS: Cytoprotection against hydrogen peroxide-induced cell death in cultured mouse mesangial cells by erigeroflavanone, a novel compound from the flowers of Erigeron annuus. Chem Biol Interact 2009, 180:414-420.

19. Jang DS, Yoo NH, Kim NH, Lee YM, Kim CS, Kim J, Kim JH, Kim JS: 3,5-Di-Ocaffeoyl-epi-quinic acid from the leaves and stems of Erigeron annuus inhibits protein glycation, aldose reductase, and cataractogenesis. Bio Pharm Bull 2010, 33:329-333.

20. Jeong $\mathrm{CH}$, Choi GN, Kim JH, Kwak JH, Kim DO, Kim YJ, Heo HJ: Antioxidant activities from the aerial parts of Platycodon grandiflorum. Food Chem 2010, 118:278-282

21. Chang ST, Wu JH, Wang SY, Kang PL, Yang NS, Shyur LF: Antioxidant activity of extracts from Acacia confuse bark and heartwood. J Agric Food Chem 2001, 49:3420-3424.

22. Heo HJ, Cho HY, Hong B, Kim HK, Kim EK, Kim BG, Shin DH: Protective effect of 4',5-dihydroxy-3',6,7-trimethoxyflavone from Artemisia asiatica against A $\beta$-induced oxidative stress in PC12 cells. Amyloid 2001, 8:194-201.

23. Rice-Evans CA, Miller NJ: Antioxidant activities of flavonoids as bioactive components of food. Biochem Soc Trans 1996, 24:790-795.

24. Zheng W, Wang SY: Antioxidant activity and phenolic compounds in selected herbs. J Agric Food Chem 2001, 49:5165-5170.

25. Lim EK, Higins GS, Li Y, Bowles J: Regioselectively of glucosylation of caffeic acid by a UDP-glucose: glucosyltransferase is maintained in planta. Biochem J 2001, 373:987-992.

26. Sul DG, Kim HS, Lee DH, Joo SS, Hwang KW, Park SY: Protective effect of caffeic acid against beta-amyloid-induced neurotoxicity by the inhibition of calcium influx and tau phosphorylation. Life Sci 2009, 84:257-262. 
27. Devipriya N, Sudheer AR, Menon VP: Caffeic acid protects human peripheral blood lymphocytes against gamma radiation-induced cellular damage. J Biochem Mol Toxicol 2008, 22:175-186.

28. Müller WE, Romero FJ, Perovic S, Pergande G, Piloglou P: Protection of flupirtine on beta-amyloid-induced apoptosis in neuronal cells in vitro: prevention of amyloid-induced glutathione depletion. J Neurochem 1997, 68:2371-2377.

doi:10.1186/1749-8546-6-25

Cite this article as: Jeong et al:: Neuroprotective and anti-oxidant effects of caffeic acid isolated from Erigeron annuus leaf. Chinese Medicine 2011 6:25.

Submit your next manuscript to BioMed Central and take full advantage of:

- Convenient online submission

- Thorough peer review

- No space constraints or color figure charges

- Immediate publication on acceptance

- Inclusion in PubMed, CAS, Scopus and Google Scholar

- Research which is freely available for redistribution

Submit your manuscript at www.biomedcentral.com/submit
Ciomed Central 